\title{
三叉神経痛症例に対する直視下アルコールプロックの検討
}

\author{
野村 健・白川正順・咲間 茂 \\ 伊藤隆康・都田芳弘・長谷川秀行
}

\section{The alcohol blocking orthoptically by exposing the nerve operatively}

\author{
Takeshi Nomura - Masayori Shirakawa - Shigeru Sakuma \\ Takayasu Ito $\cdot$ Yoshihiro Toda $\cdot$ Hideyuki Hasegawa
}

\begin{abstract}
Trigeminal neuralgia is one of the diseases which we encounter frequently in oral surgery. The treatments for this disease are mainly symptomatic therapies such as pharmaceutical treatment and nerve blocking treatment, but the existing circumstances are that none of these methods has a decisive effect, and is unable to produce a favorable result in many cases.

The authors have experienced 2 refractory cases which were clinically diagnosed as idiopathic trigeminal neuralgia. The patients repeatedly developed pain, though pharmaceutical treatment or various other treatments such as alcohol blocking were made. Therefore, various studies have been made for the treatments, and an attempt has been made to perform alcohol blocking orthoptically by exposing the nerve operatively. As a result, favorable progress has been observed without recurrence so far, which we report here with some of our consideration added.
\end{abstract}

key words: trigeminal neuralgia, alcohol block

緒

\section{言}

三叉神経痛は口腔外科領域において少なからす遭遇す る疾患のひとつである，従来より本症に対する治療法は 薬物療法, 神経ブロック療法, といった対症療法が主体 として行われてきたが，いずれの療法も決め手に欠け多 くの場合は良好な結果が得られないのが実状のよらであ る.

今回著者らは，突発性三叉神経痛之臨床診断し，薬物 療法あるいはアルコールプロックなどの種々の療法を試 みたにもかかわらず，再三にわたって疼痛発作を繰り返 した難治性三叉神経痛の 2 症例に遭遇した。 そのためこ れらの症例に対する処固法について種々検討を加兄, 明 視下に神経を露出させ，直接アルコールブロックを行 ら方法を試みた。 その結果, 現在まで再発もなく良好経 過が得られたのでその概要を報告するとともに若干の考

町田市民病院口腔外科

（主任：白川正順医长）

Department of Oral and maxillo-facial Surgery, Machida Citity Hospital (Chief: Dr. Masayori Shirakawa)

受付日：昭和62年11月25日
察を加える.

症例

\section{症例 1}

患 者: 43歳 男性.

初診日：昭和 59 年 10 月回日.

主 訴：右側煩部の電撃様疼痛.

既往歴・家族歴：共に特記事項はなかった，

現病歴: 昭和59年 9 月下旬, 近医にて $\underline{6}$ | の拔歯術を 受けた。術後は順調で著変なく経過していたが, 約 1 か 月前より洗顔時, 右側眼窩下部を中心とする電撃様疼痛 が発現した．軽快することなく何日にもわたって間断な く疼痛が持続したため, 不安になり当科に来院した。

現 症

全身所見：体格は中等度，栄養状態は良好で，全身所 見には特記すべき事項は認められなかった。顔貌は左右 対称であったが持続性疼痛によりやや憔悴気味であっ た。また，右番翼部をトリガーゾーンとして右眼窩下部 を中心とする疼痛発作を強く訴えた（写真１）.

口腔内所見：歯牙の欠損扰よび補緅的処固を認めた が，疼痛の原因となる所見は認められなかった。

$\mathbf{X}$ 線所見 : 疼痛の原因となる所見は認められなかった 
(写直 2).

㰓床検査所見：特に異常値は認められなかった。

処置および経過：初診時, 䫇顔面領域における異常所 見を羿めないため，同日当院脳神経外科に対診を依頼し たが，異常の指摘を受けなかった。そのため突発性三叉 神経痛と臨床診断し，昭和59年11月日よりまずは保存 的治療として，カルバマぜピン $600 \mathrm{mg}$ およびビタミン B 群の内服投与を行った。乙かし臨床症状は一進一退で

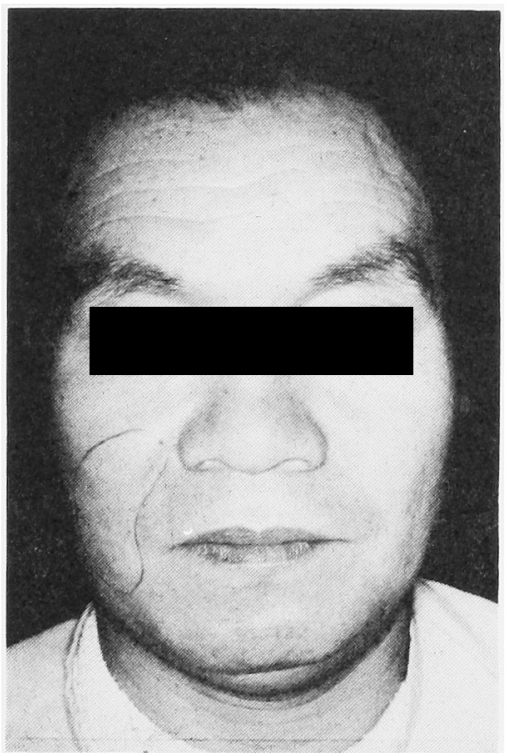

写真 1 症例 1 初診時顔貌 疼痛発現域を示す
軽快のきざしをみせなかった，ところが投薬 2 か月後の 昭和60年 1 月初旬より症状の軽快が認められ，同年 2 月 下旬不快症状は完全消失した。そのため一時休薬し䋊過 観察を行った。

同年10月下旬，会話時および上下唇の接触により以前 と同様の疼痛発作が生ずるようになったため，薬物療法 を再開し投薬で約 9 か月間経過観察した，そのらら眠気 などの副作用が発現したためカルバマゼピンを減量した ところ疼痛は増強する一方であった。

そこで昭和61年 7 月より星状神経節ブロックを週 2 回 反復 2 週施行したが一向に効果が得られなかった。その ため，8月日右側眼䈑下へのアルコールブロックを施 行した (写真了). しかし，アルュールブロックの奏効 は一度で得られず，再度，反復施行した，その結果，一 時軽快のきさしをみせたがつかの間で，再発を認めたた めこれまでの経過を検討しやむなく眼窩下孔の open method Kよるアルュールブロックを計画した. open method による直達アルコールブロック施行後は不快事

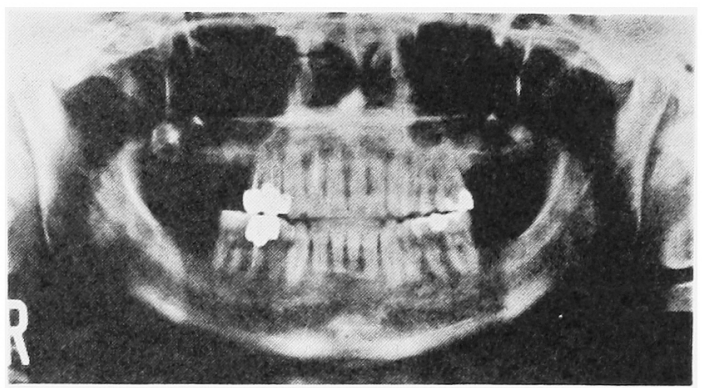

写真 2 症例 1 初診時パントモ写真

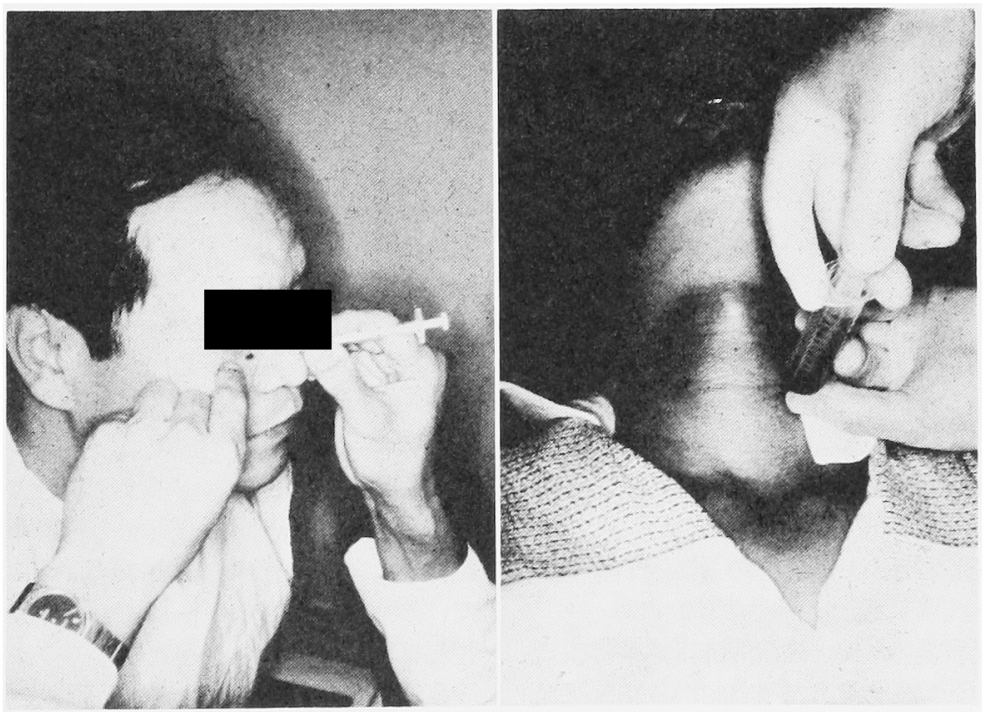

写真 3 症例 1 アルコールブロック括よび狌状神経節ブロック坆行時 


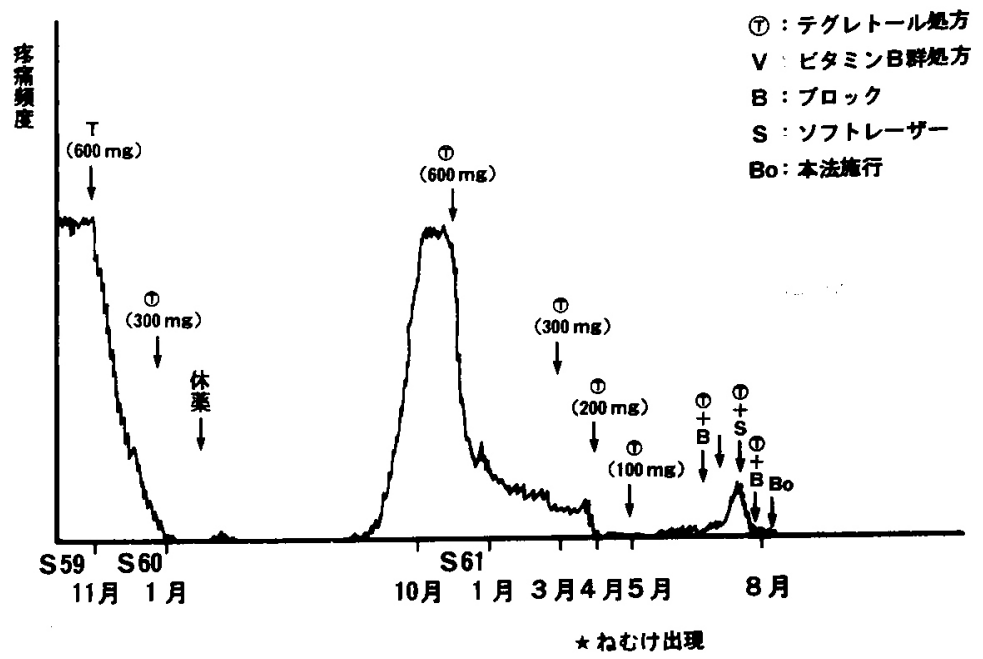

図 1

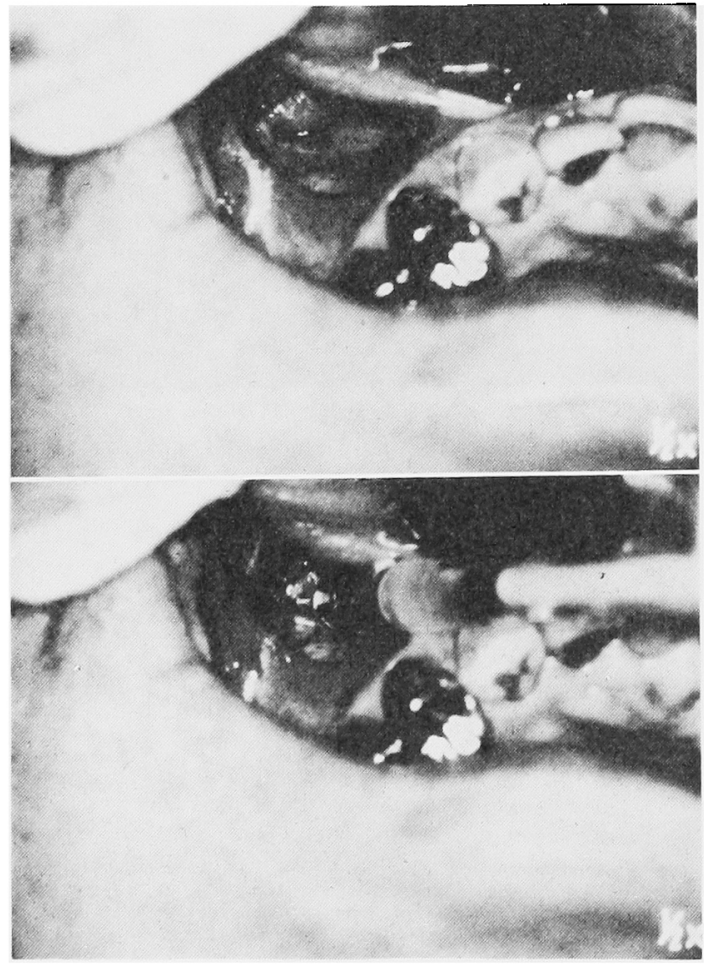

写真 4 症例 1 術中写真

項もなく疼痛発作は完全消失し，約10か月経過した現在 まで再発を諗めない（図 1).

本法の術式： $2 \%$ キシロカイン漫潤麻酔下に犬歯相当 部唇煩移行部に骨膜下に達する $2 \sim 3 \mathrm{~cm}$ の横切開を加 え，眼窩下部に向けて骨膜剩離を行った，次に眼窩下神

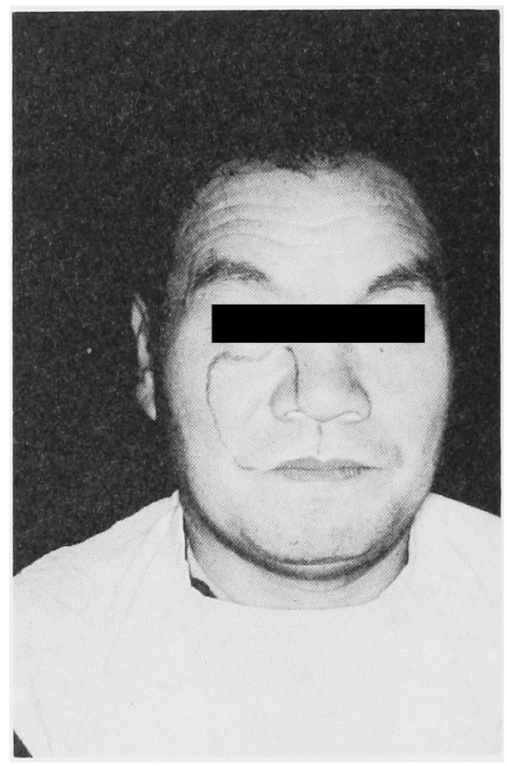

写真 5 症例 1 奏㚳範囲を示す

経を露出させ，眼窩下孔内に1.0\%キシロカイン $0.4 \mathrm{ml}$ を注入した，約20分後異常のないことを確認したのち周 囲組織にェタノールが流出しないよら十分注意しながら $99.5 \%$ ヌノール0.2 $\mathrm{ml}$ を眼窩下孔内に注入した（写真 4). 注入後は，止血を確揌し粘膜骨膜升をもとに復し 創の释合閉鎖を行い施術を終了した. 術後経過は良好 で，疼痛発作などの不快事項るなく10か月経過した現在 再発は認められない(写真 5).

症例 2

患 者: 58歳 女性. 


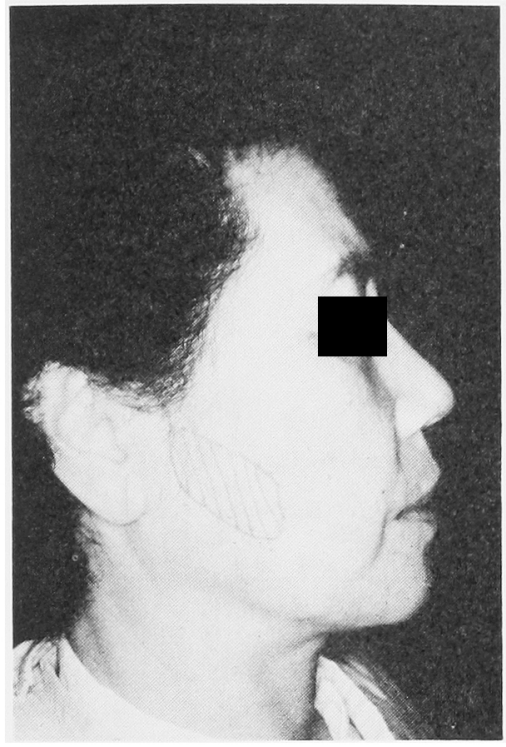

写真 6 症例 2 初診時顔貌所見 疼痛発現領域を示寸

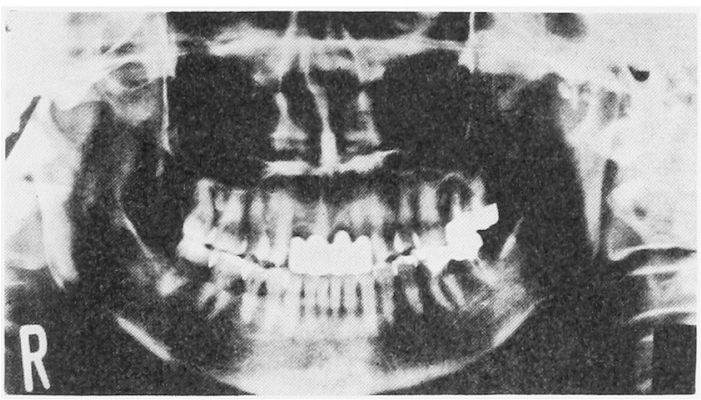

写真 7 症例 2 オルソパントモ写真

初診日：昭和58年 1 月日日。

主 訴: 右側吽部疼痛.

既往歴ならびに家族歴 : ともに特記事項はなかった。

現病歴：昭和57年10月頃より洗顔時右側煩部の一過性 疼痛を自覚したが生活に支障ないため放䈯した。ところ が，同年12月頃より同部間歇的な電撃様の疼痛が発現 し，再三にわたって繰り返すようになった。そのため， 近医耳奥科を受診したが暴常はないといわれ，精神安定 剤の投薬を受けた，しかし一向に改善しないため某大学 病院耳鼻科を受診した。 三叉神経痛と䛦断され薬物療法 を主体とし約 3 か月間通院治療を受けたが症状は改善し なかった，そこで，近医歯科を転々としたのら昭和58年 1 月曰日当科を紹介され来科した。

現 症

全身所見：体格，栄養状態は中等度で，全身所見には 特記すべき事項を認めなかった，顔貌は左右対称で，疼

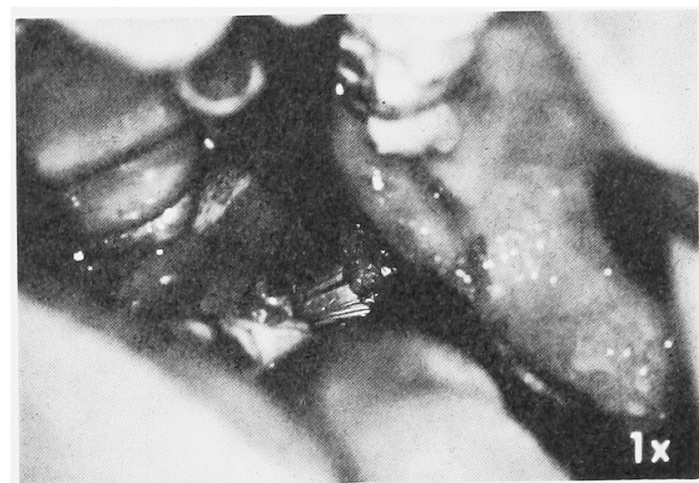

写真 8 症例 2 術中写真

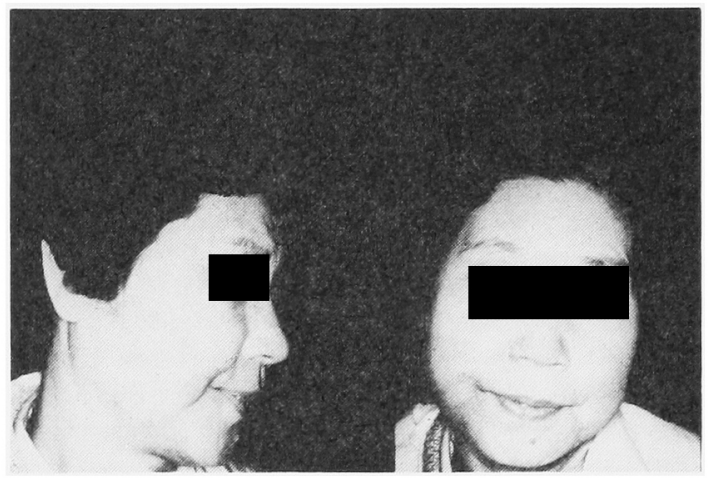

写直 9 症例 2 術後贿貌写真

痛域は左側下唇部をトリガーゾーンとして受診中にも右 煩部に発作的に放散痛を生じた（写真 6).

口腔内所見：口腔内は補浆的処置が施されているが疼 痛の原因となる特異的所見は認められなかった。

X線所見：疼痛の原因となる雪性疾患あるいは矤骨疾 患は認められなかった（写真 7 ).

臨床検査所見：特に異常值は認められなかった。

処置および経過 : 種々精查した結果疼痛源が認められ なかったため，特発性三叉神経痛の臨床診断のもとにま ず辢定的にカルバマビピン $600 \mathrm{mg} /$ 日を約 1 か月にわた って内服させた，ての結果, 疼痛㱏状の一時改善をみた ため，投薬を中止し経過観察を行っていたところ，投薬 中止から約 1 年 2 加後, 初発時と同様の電撃様の疼痛 発作が生じたため再来した。 そのため前回同様，カルバ マゼピン $600 \mathrm{mg}$ の投薬を約 5 か月間にわたって内服さ せた. 昭和 60 年 1 月やっと疼痛のコントロールが得られ たため一時休薬し，経過観察とした。

その後昭和61年 7 月まで疼痛発現, 投薬, 疼痛楥解之 いら経過を数回繰り返した，疼痛発現までの期間が徐々 に短縮し疼痛の程度も泍次増強傾向をみせた。そのため 種々検討を加え，治療方針を open method に上る直達 


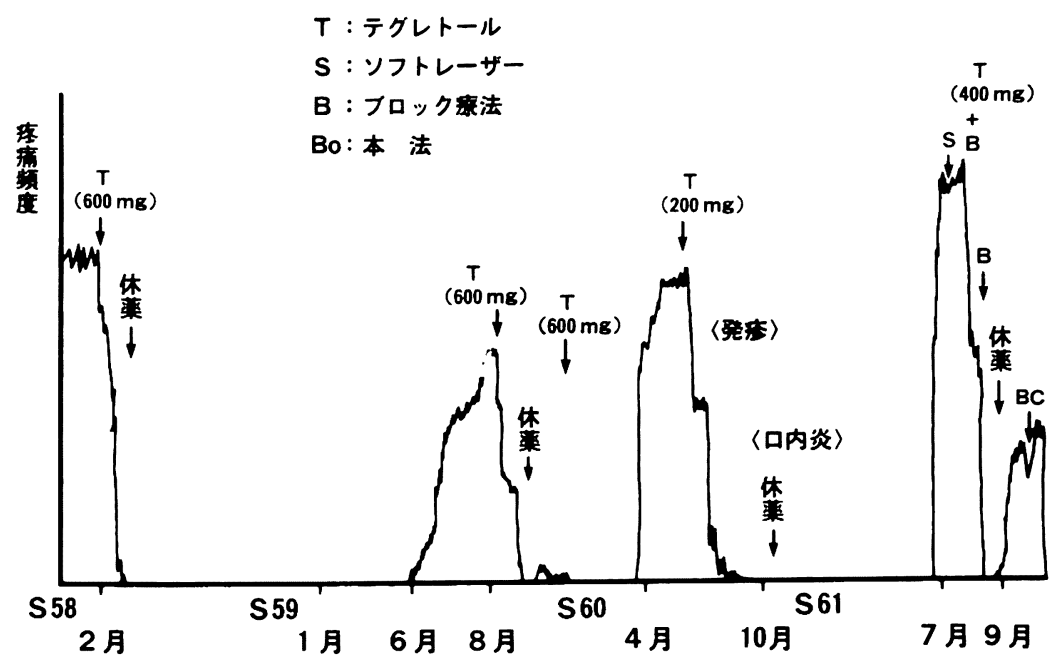

図 2

アルコールブロック療法に変更した。

まず疼痛源を確認するため, キシロカインによる局所 麻酔試験を行った。 下顎孔伝達麻酔により疼痛のコント ロールが可能で, 頓神経およびオトガイ神経部での麻酔 は無効であった。したがって, 疼痛領域が下米槽神経に あると臨床診断した。

術 式: 静脈内鎮静を併用し， $2 \%$ キシロカイン局所 麻酔下に顎間䈴譬部に下顎枝矢状分割に準じた粘膜骨膜 切開を加えた。次に, 下䫇枝内面に沿って骨膜を剝離 し, さらに下顎孔を露出させたのちカテラン針の先端を 約 $90^{\circ}$ に屈曲させこの先端を下顎孔内に挿入し神経ブロ ックを行った. 薬剤の注入方法は症例 1 と同様で, 初め に $1 \%$ キシロカイン $0.4 \mathrm{ml}$ を注入し約 20 分間経過を観 察し，異常のないことを確認した後 $99.5 \%$ ェタノール $0.2 \mathrm{ml}$ を注入した（写真 8 ). その後通法に従って創の 完全閉鎖を行い手術を終了した。

術後経過：処置後, 顔面半側にび漫性浮腫が出現し, 同時に内出血斑が生じた（写真 9 ).

さらに, 患側煩部には激烈な持続性疼痛が発現し, む しろ增悪傾向を示した。しかしこの疼痛は約10日後, 腫 脹の軽減に伴い徐々に消失した。処置後約 4 か月を経過 した現在, 疼痛発作は発現せず経過は良好である（図 2).

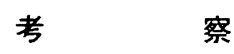

三叉神経痛は，従来より原因不明とされる突発性三叉 神経痛と，明らかな原因から継発する症候珄三叉神経痛 に分類されている。この両者は神経症状の有無や疼痛の 様式などに明らかな相違があるため診断は比較的容易で
ある ${ }^{1 \sim 3)}$. 近年になり原因が明らかでないとされていた 突発性のものに対して, Jannetta ${ }^{4 \sim 8)}$ らは後頭蓋窩開頭 手術による所見から, 三叉神経根における vascular cross compression の重要性を報告した．その後諸家の臨床追 試が行われるに従って,この neurovascular compression theory が突 発性三叉神経痛の原因を解明する足がか

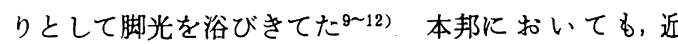

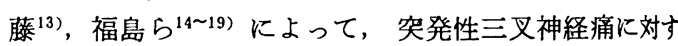
る根治的治療法として神経血管减圧術の詳細な手術手技 が報告された。神経血管減圧術は手術侵襲の小さい安全 な手術とされ良好な結果が得られているものの，一方て は全例に適応するものではないとする意見もある. 守山 $5^{20)}$ は機能的疾患が大部分である本症に対して手術法を 僈先するのは問題であるとして, 薬物療法, ブロック療 法などの保存的治療に抵抗する症例に対してのみ本手術 法を選択すべきであると主張している，また，安全な手 術法とはいえ本手術法の選択には開頭が避けられないこ と，手術を望まない患者もあること，まれではあるが㯰 力障害などの術後合併症などが報告されていることなど の点から絶対的な手術法とはまだいい難いようである. 加えて，本法は機能外科の要素の強い手術であるため患 者からの要請があるまでは，保存的治療を主体とらざる を得ないのが現状のようである21 25)

さて，今回著者らの行った方法は，基本的にはアルコ 一ルブロック療法の範鮸ではあるものの, 従来の盲目的 手術法による不確実な面が少なく神経支配領域への確実 なアルコールの注入が可能であった。 また直視下でブロ ックを行らため, 奏効が確実で, 難治性の再発症例に対 しても十分な効果が期待できるなど有利な面をもってい る. また, 術後合併症が比較的少なく, 手術操作す比較 
内簡便で, 短時間での処置が可能である. その上，特殊 な器具を必要としない点や外来での処置が可能であるな ど多くの利点をあげることができ，神経揄除術などの最 终的治療にはない有益な方法と考えられた。

ことに第 2 症例のごとく, 疼痛領域が下歯槽管内にあ る症例においては, 通常のアルコールブロック療法で は, 盲目的要素が高く, アルュール注入時針の先端によ る周囲組織の損傷の危険性が䀣念される。そのら元，手 技的にも困難なため，下顎孔の実際の位置よりかなり高 位からのブロックを選択せざるを得ず的確な奏効が得に くいと考えられる。 その点, 著者らの方法では直視下に おける選択的下歯槽神経のブロックが可能であるため, ブロック後の知覚麻痺領域も最小限にすることが可能で あると考えられた。

第 2 症例における術後の著明な腫脹と疼痛の原因につ いて種々考察してみると，下靧孔が直視しづらかったた め切開, 䟝離が必要以上に大きくなってしまったこと, 手術操作が多少長くなったこと, アルコールの注入時に アルコールが周囲組織隙に洩れたこと, 術後の神経性浮 腫が生じたことなどが要因としてあげられた。これら不 快事項を予防するための対策としては，操作中に周聿組 織にガーゼなどを包填して防湿をほとここすどの手術操 作上の注意が必要と思われた。 また，手術手技を熟練す ることによって操作時間を短縮することも重要な一つで あろ5。器具器材についてはブロックに用いるカテラン 針の先端を鈍縁化させたり, 他の器具器材の利用や新器 材の開発の必要性もあろ5。いずれにしても現段階では 暗中模索の域でありいくつかの段階を踏み越えることに よって術後の不快事項の軽減が可能であるばかりか奏効 上の向上がさらに得られると考えられた.

術後10か月経過した現在においても，2症例とも再発 がなくきわめて順調であるが，一般にアルコールブロッ クの有効期間は約 1.5 年とされており 26,27$)$, 今後さらに 経過を観察する必要があることはいらに及ばない，その ため，今後さらに症例を重ねるばかりでなく，より簡便 な手法についても考案していく所存である.

\section{結語}

著者らは各種の保存的療法を試みたにもかかわらず, 再三にわたり疼痛発作を繰り返した難治性の突発性三叉 神経痛に対して, 観血的に神経孔を露出させ直視下にア ルュールブロックを試みた 2 症例を経験した。 その結 果, 再発もなく良好な結果を得ることができたので, こ の概要を報告するとともに若干の考察を加えた。

\section{引用 文 献}

1）鈴木長明：㔖発性三叉神経痛。菌科ジャーナル
18: 819-826 1983.

2) 内田安信：非定型口腔・顔面痛。畨科ジャーナ ル 18: 837-846 1983.

3) Ronald D.: Pain Control in Dentistry: The Anatomic and Physiologic Basis of Orofacial Pain. The Compendium of Continuing Education 7: 408-416 1986.

4) Jannetta, P.J.: Arterial compression of trigeminal nerve at the pons in patient with trigeminal neuralgia. J Neurosurg 26: 1591621967.

5) Jannetta, P.J.: Trigeminal neuralgia and hemifacial spasm-etiology and definitive treatment. Trans Am Neurol Assn 100: 89-91 1975.

6) Jannetta, P.J.: Microsurgical approach to trigeminal nerve for tic douloureux. Prog Neurol Surg 7: 180-200 1976.

7) Jannetta, P.J.: Treatment of Trigeminal neuralgia by suboccipital and transtentorial cranial operations. Clin Neurosurg 24: 5385491977.

8) Jannetta, P.J.: Observations on the etiology of trigeminal neuralgia, hemifacial spasm, acoustic nerve dysfunction and glossopharyngeal neuralgia: Definitive microsurgical treatment and results in 117 patients. Neurochirurgia 20: 145-154 1977.

9) Alexander, M.R., Philip, P.P., et al.: Etiology and treatment of idiopathic trigeminal and atypical facial neuralgias. Oral Surg 48: 298-308 1979.

10) Calbucci, F., Bollini, C., et al.: Intracranial microvascular decompression for "cryptogenic" hemifacial spasm, trigeminal and glossopharyngeal neuralgia paroxysmal vertigo and tinnit: I. Surgical technique and results. Ital J Neurol Sei 7: 359-366 1986.

11) Michelucci, R., Tassinari, C.A., et al.: Intracranial microvascural decompression for "cryptogenic" hemifaciall spasm trigeminal and glossopharyngeal neuralgia, paroxysmal vertigo and tinnitu: II . Clinical study and long-term follow up. Ital J Neurol Sei 7:367-374 1986.

12) P. Richards., H. Shawdon., et al.: Operative findings on microsurgical exploration of the cerebello-pontine angle in trigenimal neuralgia. J Neurol Neurosurg Psychiatry 46:109811011983.

13）近藤明息：顎顔面痛の外科治療。菌科シャーーナ ル 18: 877-884 1983.

14）福島孝徳：三叉神経痛の外科的治療一病因論の 変遷と新しい根治手術 ( $シ$ ャネッタ法) の出現 一。神経進歩 $26: 982-9911982$.

15）福島孝镘：三叉神経痛一手術適応と効果。治療 
66: 1779-1782 1984 .

16）佐々木 亮, 早川 勲, 他:三叉神経痛扎よび

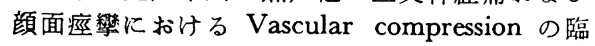
床的意義. 脳神経外科 9：473-481 1981.

17）本郷一博, 小林茂昭, 他 : 顔面痙繁おょび三叉 神経痛に対する後頭蓋䈑微小血管減圧術. 脳神 経外科 13：1291-1296 1985.

18）本郷一博, 小林茂昭, 他：顔面痙繁。三叉神経 痛に対する微小血管減圧術の術式ならびに術中 モニタ一。信州医誌 33: 220-227 1985.

19）井須豊彦, 阿部 弘, 他: 三叉神経痛の外科治 療一Jannetta 法による神経血管減圧術一. 北 海道医学雑誌 60：91-96 1985.

20）守山英二, 㛢田昌平, 他: 三叉神経痛74例の治 療経験一その原因と治療方針について一. IRYO 39: 343-348 1985.

21）野間弘康, 柿澤 卓: 口腔・顔面領域の神経 痛. 歯科シャーナル 23: 369-378 1986.

22）宮坂和男：三叉神経痛。 Pain Clinic 7：233-
2411986.

23）泉 二郎, 黒川健甫, 他 : 三叉神経痛に対する 三叉神経根の選択的電気凝固法. 医療 34:9839891980.

24) J.M. Mumford.: Role of the dentist in trigeminal neuralgia. Pain 5: 83-92 1978.

25）五十嵐正至：三叉神経痛一痛みのメカニズムと 最近の治療法一医学のあゆみ 137: 280-283 1985.

26）若杉文吉：三叉神経痛一神経ブロック療法. 治 療 66: 1773-1777 1984.

27) J.G. Phillips and R.I.H. Whitlock.: The effect an alcoholic injection for facial pain. British J Oral Surg 14: 173-178 1976.

28）野間弘康：小手復と局所解剖. 菌界展望別冊/ 歯科小手術の臨床. 1983，7-34頁.

29）金子 讓：小手術のための局所麻酔法と全身的 偶発症の管理。菌界展望別冊/歯科小手術の臨 床. 1983, 81-100頁. 